\title{
Electrospun Nanometer to Micrometer Scale Biomimetic Synthetic Membrane Scaffolds in Drug Delivery and Tissue Engineering: A Review
}

\author{
Shaleena K. Pazhanimala, Driton Vllasaliu (1) and Bahijja T. Raimi-Abraham * \\ School of Cancer and Pharmaceutical Sciences, Faculty of Life Sciences \& Medicine, King's College London, \\ London SE1 9NH, UK; shaleena.koomullukkad_pazhanimala@kcl.ac.uk (S.K.P.); \\ driton.vllasaliu@kcl.ac.uk (D.V.) \\ * Correspondence: Bahijja.Raimi-Abraham@kcl.ac.uk; Tel.: +44207-848-0622
}

Received: 21 January 2019; Accepted: 20 February 2019; Published: 4 March 2019

check for updates

\begin{abstract}
The scaffold technology research utilizes biomimicry to produce efficient scaffolds that mimic the natural cell growth environment including the basement membrane for tissue engineering. Because the natural basement membrane is composed of fibrillar protein networks of nanoscale diameter, the scaffold produced should efficiently mimic the nanoscale topography at a low production cost. Electrospinning is a technique that can achieve that. This review discusses the physical and chemical characteristics of the basement membrane and its significance on cell growth and overall focuses on nanoscale biomimetic synthetic membrane scaffolds primarily generated using electrospinning and their application in drug delivery and tissue engineering.
\end{abstract}

Keywords: basement membrane; BM; fiber; nanofibers; electrospun; scaffold

\section{Introduction}

Engineering synthetic membrane scaffolds for in-vitro tissue growth constitutes a large portion of research in the field of biomaterial sciences [1]. The major challenge in this field is to mimic the three-dimensional (3D) topography of the natural cellular microenvironment, which has a significant role in modulating cell behavior [2]. The physical and chemical signals from these microenvironments regulate the gene and protein expression, as well as proliferation, differentiation and migration of cells [2].

The basement membrane (BM) is a highly specialized supporting structure of the extracellular matrix to which the cells adhere [3]. Currently, there is a significant need to fabricate in-vitro tissue models, including mucosal models that emulate the in vivo tissue to study drug delivery, entry mechanisms of infectious agents and nutrition transport [4-7]. This can only be achieved by fabricating a synthetic BM which promotes efficient cell proliferation, migration, and differentiation [3]. Currently, there are several nanofabrication techniques that are capable of producing 3D scaffolds with varied dimensions (nanometer to micrometer size) and geometry (varied pore size and topographical patterns) [8]. They range from traditional techniques such as particle leaching (i.e., porous polymer matrix produced by leaching of porogen) and freeze drying (i.e., using thermodynamic instability to create a porous matrix) to more advanced and controlled techniques such as lithography (pattern transfer method) and bioprinting (3D printing of prepolymer solution in a layer-by-layer process) $[8,9]$. However, electrospinning is still considered a popular, low-cost and effective technique to fabricate a synthetic BM with nano-scale topography [10].

This review discusses the physical and chemical characteristics of the basement membrane, its significance on cell growth and an overall focus on biomimetic synthetic membrane scaffolds in the 
nanometer to micrometer scale primary generated using electrospinning and their application in drug delivery and tissue engineering.

\section{Understanding the Basement Membrane}

The $\mathrm{BM}$ is a specialized form of an extracellular matrix (ECM) found underneath all polarized epithelial cells of eumetazoans [11-13]. It is a dynamic structure that is constantly deposited and modified by the epithelial cells, endothelial cells and fibroblasts [12,14]. The BM not only provides mechanical support to the overlying tissues but also regulates tissue architecture and its function by interacting with the cells and the surrounding environment [12]. Hence, there is a variation in the BM thickness, composition and function with its location (cell type), physiological state and pathophysiological state [12,15].

BM is broadly divided into three layers, namely lamina lucida, lamina densa and lamina fibroreticularis. Of the three, lamina densa is the most important layer, which is separated from the cells and the extracellular matrix by lamina lucida and lamina fibroreticularis, respectively [11]. Lamina lucida is a less dense zone, through which the components of lamina densa interact with the cell surface receptors (integrin and non-integrin proteins) [11,16] The thickness of lamina fibroreticularis, on the other hand, varies from place to place with a well-demarcated structure under the respiratory epithelium to entirely absent in capillary walls of the kidneys [11].

The core components of lamina densa are type IV collagen, laminin, nidogen, and heparin sulfate proteoglycan/perlecan of which type IV collagen and laminin form two independent, self-polymerizing networks that are connected to one another by nidogen and perlecan [17]. Laminin is a heterotrimer made of $\alpha, \beta$ and $\gamma$ chains, which form a cruciform structure, whereas type IV collagen is a heterotrimer made of three different types of alpha chains [16]. The complex assembly of the BM is initiated by the binding of laminin to cell surface receptors such as sulfated glycolipid, integrin, and dystroglycan [18]. Once bound, a cascade of reactions takes place starting with self-polymerization of laminin, accumulation of other core components, bridging of laminin to type IV collagen by nidogen and polymerization of type IV collagen to form the covalently stable network [18]. Although this network provides the BM with its characteristic mechanical strength, their receptor binding and cell signaling properties differ with the kind of core component isoforms [18]. For instance, there are three isoforms of type IV collagen and 16 different isoforms of laminin distributed in different BM in a tissue-specific manner, imparting it with its unique structure and function [19]. Other components of BM are collagen III, collagen V, collagen VI, collagen VII, collagen XVII and collagen XVIII [19]. The $\mathrm{BM}$ is also a reservoir filled with growth factors such as transforming growth factor $\beta$, fibroblast growth factor, vascular endothelial growth factor, and heparin epidermal growth factor, as well as various proteases and cytokines, making it the most complex structure to be synthetically replicated in-vitro $[11,19,20]$. Moreover, their dynamic nature and modification with age and disease adds to the challenge.

Nanotopography of the BM plays a very important role in cell growth and function [21]. The nanoscale variations on the surface present the cell with contact guidance, which modulates the cellular response in many ways [21]. Similarly, the size, geometry, roughness, stiffness, and porosity of the synthetic scaffold significantly control the cell behavior [22,23]. Hence, to efficiently fabricate a synthetic membrane in vitro, it is important to understand the topography of the native BM.

Generally, BM is considered to be of $<100 \mathrm{~nm}$ thickness with $400 \mathrm{~nm}$ long collagen IV forming a flat horizontal stretch along the interconnected network [24,25]. However, this configuration of the BM does not provide the amount of flexibility required during tissue growth and for organs (e.g., skin, lung, and vasculature), which are constantly changing their shape [26]. However, as discussed above, the thickness of the BM increases with age, providing the flexibility that is otherwise impossible for a $<100 \mathrm{~nm}$ thick membrane $[27,28]$. Moreover, type IV collagen was proposed to be in a mesh-like configuration, providing extensibility for growth and development [28]. 
Stiffness and roughness are the two other factors that govern the attachment of cells on the BM. There are two sides to the BM: the epithelial side, which is attached to the cells, and the stromal side facing the extracellular matrix $[29,30]$. Recently, atomic force microscopy (AFM) study to determine the polarity of both sides showed that the epithelial side is around two to four times stiffer than the stromal side $[29,30]$. It was also determined that laminin is more localized to the epithelial side of the $\mathrm{BM}$ and collagen to the stromal side [30,31]. Similarly, AFM study of the inner limiting membrane (ILM- the BM at the vitreal surface of the human retina) indicated the retinal side (cellular side) to be significantly rougher compared to the vitreal side (stromal side) [29].

\subsection{Influence of Age on the Basement Membrane}

Cardiello et al. (2010) studied the ILM of different age groups (samples from fetal stages to 90 years old) [27]. He observed that there is a steady increase in ILM thickness, from $70 \mathrm{~nm}$ at fetal stages to $1500 \mathrm{~nm}$ by 83 years of age. Biochemical changes, such as a relative increase in type IV collagen with a decrease in laminin concentration, was also observed [27]. On the other hand, a similar study on human skin epithelial BM showed an inverse relationship between the concentration of type IV collagen and BM thickness [32]. It was observed that collagen content in the skin BM decreased with age as the total thickness increased suggesting a decrease in tissue turnover [32]. Age-related increase in thickness was also demonstrated in the BM of human corneal epithelium [33], rat testis [34] and rat glomerular BM [35]. In the human corneal epithelial BM, two processes of age-dependent thickening were observed. From the fetal stage to the first 20 years continuous deposition of membrane components onto the unilaminar membrane was the prime cause of thickening [33]. However, after that stage, reduplication of the membrane was the main reason for thickening during which the unilaminar membrane was converted to multilaminar BM [33]. All the above data clearly demonstrate that, with age, there is a steady increase in BM thickness along with significant biochemical changes such as a difference in protein concentration.

\subsection{Influence of Disease on the Basement Membrane}

The significance of the BM and its change with the disease was first established in Alport syndrome (progressive loss of kidney function), caused by the mutations in alpha 3, alpha4 and alpha 5 type IV collagen genes (COL4A5, COL4A3 or COL4A4) coding for Type IV collagen [36]. This causes progressive thickening and multilamellation of the glomerular BM [37]. Since then, many human genetic diseases, such as Pierson syndrome (abnormalities in eye and kidney failure), Knoblock syndrome (eye diseases), HANAC syndrome (Hereditary Angiopathy with Nephropathy, Aneurysms and Muscle Cramps), merosin deficient congenital muscular dystrophy and epidermolysis bullosa (skin fragility disorder), caused by mutations in BM components, were observed [36]. Inflammatory diseases such as asthma (airway inflammation) and collagenous colitis (nonspecific inflammatory bowel diseases) are also known to be associated with an increase in the thickness of the subepithelial BM $[38,39]$.

Different cells such as leukocytes, trophoblasts, and cancer cells are known to breach the BM [13]. For instance, neutrophils and monocytes pass through the discontinuous patchy regions of the BM called "low expression regions" during inflammation [15]. On the other hand, cancer cells gradually change the composition of the stroma and increase the number of fibroblasts and macrophages with the eventual release of protease and tumor invasion [15].

\subsection{Importance of Basement Membrane in Tissue Engineering}

BM plays a vital role in shaping tissue architecture [12]. For instance, deposition of BM protein laminin during the development of Madin-Darby Canine kidney cells in vitro was observed to inflict polarization of cells. This, in turn, helped in organizing the group of cells into a cyst-like monolayer, with a lumen [40]. Laminin accumulated side of the cell became the basolateral domain and the cell surface facing the lumen became the apical domain. Another important function of BM was 
observed in vertebrate and invertebrate embryo where the constrictive force exerted by the type IV collagen restricted the growth along the dorsal ventral axis while permitting anterior-posterior elongation [41,42]. Moreover, remodeling of the BM is another well-known function that brings stable connections between two adjacent tissues [12,43]. This clearly signifies the importance of BM as a scaffold in the field of tissue engineering.

\subsection{Importance of the Basement Membrane in Drug Delivery}

In the field of macromolecule and nanomedicine drug delivery, the molecular barrier is extensively researched with the view of achieving non-invasive delivery of the therapeutics $[3,44]$ and the understanding of some of the component barriers of the mucosae has helped in developing effective drug delivery strategies against these barriers [45]. However, the barrier function of BM in drug delivery studies is a field that is not fully appreciated. An earlier study by Alfano et al. observed the penetration of smaller macromolecules of size $5 \mathrm{kDa}$ was restricted by non-keratinized oral mucosal epithelial BM [46]. A more recent study by Vllasaliu et al. using decellularized BM produced by airway epithelial cells also demonstrated the size dependent restriction of macromolecular diffusion [3]. Both studies clearly signify the importance of BM as a drug delivery barrier and hence further research on its barrier function is mandatory to build efficient mucosal drug delivery strategies.

\section{Electrospinning}

Electrospinning is a rapidly-emerging but old technique which was first observed a century ago [10]. Since then, it has been rediscovered and constantly refined. Currently, electrospinning can produce high-quality fibers with nanoscale diameter from a variety of natural and synthetic polymers $[10,47]$. The electrospinning equipment is simple with just four major components: a high voltage power supply, a syringe pump, a spinneret and a collector) [10,48]. When a high voltage is passed on to the spherical droplet of viscoelectric fluid (polymer dissolved in a suitable solvent), pumped through a spinneret, the surface of the droplet will be covered by electric charge [10]. This charge on the surface instantly start repelling the surface tension which holds the droplet in its sphere shape. Once the repelling force overcomes the surface tension, the spherical drop will deform into a conically shaped structure called Taylor cone with the eventual release of a jet of fibers as the solvent evaporates [10]. The combined action of the electric field, repulsion forces and the whipping motion of the fiber jet remarkably reduces the diameter of the fiber to a nanoscale dimension [10]. These nanofibers offer a very high surface area to volume ratio. Moreover, their properties can be easily tuned by varying the electrospinning parameters and solution properties, making it the most versatile method for producing fibers of submicron range at a very low cost [47,49]. Hence, nanosized materials made by electrospinning have a broad range of application in the electronics, biomedical sciences, biotechnology, textile, energy and environmental sectors [50-55].

\subsection{Biomimetic Applications of Electrospun Nano Structures for Tissue Engineering Purposes}

The tissue engineering application of the electrospun nanofibrous scaffolds is attributed to its ability to mimic the biological environment (BM or ECM) which provides both the biochemical and biophysical information required for efficient cell adhesion, proliferation, differentiation and migration [48-50]. This biomimetic ability of the electrospun scaffold has been harnessed in the field of tissue engineering to regenerate various tissues such as muscle, bone, skin, cartilage, nerve, ligament and liver [48-50]. Biomimetic nanofibrous scaffolds produced by electrospinning can be broadly classified into three major types based on the type of polymer used: electrospun nanofibrous scaffolds based on natural polymers, scaffolds fabricated from synthetic polymers and scaffolds made by co-spinning both natural and synthetic polymers [54].

Electrospun nanofibers of 500-800 nm diameter with high porosity and effective mechanical property were produced by Li et al. using poly (lactic-co-glycolic acid) (PLGA) [55]. They showed that the nanofibers promoted cell adhesion due to their close resemblance to the nanoscale environment of 
the extracellular components [55]. This preference for cells to adhere and spread in nanoscale fibers was also observed in mouse fibroblast cells seeded on PLGA nanofibers and smooth muscle cells seeded on PLCL clearly indicating that the nano-topography of the BM and the ECM has to be replicated in vitro to successfully influence cell adhesion, proliferation, and phenotypic behavior $[55,56]$.

Poly ( $\varepsilon$-caprolactone) (PCL) is another synthetic thermoplastic polymer that is extensively used in tissue engineering to make nanofibrous scaffold. Cells seeded on PCL nanofibers have displayed maturation and differentiation [54]. For instance, fetal bovine chondrocytes matured and started expressing type II collagen when seeded on to PCL nanofibers. Similarly, human marrow stromal cells differentiated into different cell lineages (adipogenic and chondrogenic) based on the type of culture media, when seeded on nanofiber PLC scaffolds [57,58].

The nanofibers made of natural polymers not only mimic the nanoscale topography of the BM and ECM components but also it has the inbuilt biological and chemical properties for cell adhesion and growth. Collagen is one such example, which is one of the most abundant structural proteins in vertebrates [59]. It is made up of three long polypeptide chains twisted to each other in a triple helix structure providing it with its characteristic mechanical strength and elasticity [57]. Collagen types I, II, III and IV are commonly used to make nanofibrous scaffolds [59,60]. Collagen nanofibers of diameters $250 \mathrm{~nm}$ (type III) and $100 \mathrm{~nm}$ (type I) were produced by Matthews et al., which exhibited successful adhesion and penetration of aortic smooth muscle cells. He observed that the property of the fibers largely depends on the type of collagen used [61]. Moreover, they exhibited successful adhesion and penetration of aortic smooth muscle cells into the engineered matrix. Collagen IV in hexafluoroisopropanol (HFIP) solvent also demonstrated the production of fibers in a size range from $100 \mathrm{~nm}$ to $2 \mu \mathrm{m}$ [62]. To increase the stability, elasticity and tensile strength of the collagen fibers, crosslinking agents such as glutaraldehyde, 1-ethyl-3-(3-dimethylaminopropyl) carbodiimide hydrochloride (EDC) and genipin (natural crosslinking agent from fruits of Gardenia jasminoides) are also in use $[52,60]$.

Similarly, other natural polymers such as gelatin (denatured collagen), elastin (a structural protein in the ECM of connective tissue), silk fibroin, fibrinogen (plasma serum protein), laminin, chitin, and chitosan are also used to successfully produce electrospun nanofibers, and as scaffolds for efficient cell growth [60].

Natural polymers are biocompatible with inherent cell adhesion properties and are less immunogenic when compared to synthetic polymers [47]. However, the fibers produced from these materials are not as strong as synthetic counterparts. Furthermore, they also exhibit uncontrollable degradation rates [60]. On the other hand, the mechanical properties and degradation rates of synthetic polymers can be easily modified [60]. Hence, currently, a blend of both natural and synthetic polymers is largely preferred to fabricate electrospun nanofibers to exploit their respective strengths [60]. He et al. co-electrospun collagen type I with poly (L-lactic acid)-co-poly( $\varepsilon$-caprolactone) (PLLA-CL) to produce nanofiber scaffolds, which enhanced the growth of human artery endothelial cells [63]. Another method to use multiple polymers is by layering individual fiber meshes one on top of another by sequential electrospinning. This was performed by Kidoaki et al. by making a tri-layered scaffold composed of nano- and microfibrous mesh of styrenated gelatin, type I collagen and segmented polyurethanek which mimicked the native environment of arteries [64]. PCL/collagen composites are one of the most extensively studied polymer blends that can be easily electrospun into nanosized fibers (210-225 nm), known to withstand high-pressure flow and proven to have in vivo stability [64] A significant increase in cell proliferation was also observed with these systems when compared to that of pure PCL nanofibers [64]. Gelatin is a cheaper alternative to collagen which has similar biochemical property, but higher tensile moduli than collagen [60]. It has also been electrospun with PCL to produce nanofibers and was observed that with an increase in total polymer concentration there is a proportional increase in fiber diameter [60,65-67]. Table 1 lists the recent examples of different electrospun scaffolds made of collagen, gelatin or laminin. 
Table 1. Examples of electrospun nanofibrous scaffold for tissue engineering purpose, the polymers used along with the properties and application of the scaffold.

\begin{tabular}{|c|c|c|c|c|}
\hline $\begin{array}{l}\text { Composition of } \\
\text { Nanofibers }\end{array}$ & Applications & Property & Author & Year \\
\hline $\begin{array}{l}\text { PCL/gelatin } \\
\text { composite }\end{array}$ & $\begin{array}{c}\text { Nerve tissue } \\
\text { engineering-Human } \\
\text { Scalp Adipose-Derived } \\
\text { Mesenchymal Stem } \\
\text { Cells (SADS) }\end{array}$ & $\begin{array}{l}\text { Nanofibrous scaffold coated with } \\
\text { platelet rich plasma. Cell } \\
\text { proliferation and differentiation } \\
\text { into neural cells observed. }\end{array}$ & Fesharaki et al. [65] & 2018 \\
\hline $\begin{array}{l}\text { PVA/collagen } \\
\text { composite }\end{array}$ & $\begin{array}{l}\text { Human lung epithelial } \\
\text { cell A549 }\end{array}$ & $\begin{array}{l}\text { Glutaraldehyde crosslinking, } \\
\text { epithelial mesenchymal transition } \\
\text { observed in nanofibers with a } 170 \\
\text { nm average diameter }\end{array}$ & Li et al. [68] & 2018 \\
\hline $\begin{array}{l}\text { PMMA coated } \\
\text { with collagen and } \\
\text { laminin }\end{array}$ & $\begin{array}{l}\text { Human myoblast and } \\
\text { fibroblast cell growth }\end{array}$ & $\begin{array}{l}\text { PMMA average fiber diameter = } \\
360 \text { nm, Genipin was used as a } \\
\text { crosslinking agent, collagen } \\
\text { promoted fibroblast proliferation } \\
\text { and laminin promoted } \\
\text { myoblast proliferation }\end{array}$ & Zahari et al. [63] & 2017 \\
\hline PLA & $\begin{array}{l}\text { Neural tissue } \\
\text { engineering }\end{array}$ & $\begin{array}{l}\text { PLA functionalized with } \\
\text { polyallylamine and epidermal } \\
\text { growth factor was covalently } \\
\text { grafted to the amine group }\end{array}$ & Haddad et a 1. [69] & 2016 \\
\hline $\begin{array}{l}\text { PCL/collagen } \\
\text { composite }\end{array}$ & $\begin{array}{c}\text { Human Wharton's jelly } \\
\text { mesenchymal stem } \\
\text { cells }\end{array}$ & Fiber diameter $=542-633 \mathrm{~nm}$ & Lafond et al. [70] & 2015 \\
\hline $\begin{array}{l}\text { poly (L-lactic } \\
\text { acid)/gelatin }\end{array}$ & $\begin{array}{l}\text { Vascular tissue } \\
\text { engineering-Human } \\
\text { umbilical vein } \\
\text { endothelial cells, } \\
\text { smooth muscle cells }\end{array}$ & Fiber diameter $=100-500 \mathrm{~nm}$ & $\begin{array}{l}\text { Shalumon et al. } \\
\text { [71] }\end{array}$ & 2015 \\
\hline PLGA/gelatin & Stem cell culture & $\begin{array}{l}\text { Fiber diameter }=267 \mathrm{~nm} \text {, gelatin } \\
\text { enhanced the hydrophilicity, } \\
\text { the scaffold was imbedded with } \\
\text { mesoporous silica nanoparticles to } \\
\text { improve tensile strength, cell } \\
\text { attachment and proliferation. }\end{array}$ & Mehrasa et al. [72] & 2015 \\
\hline $\begin{array}{l}\text { PCL/gelatin } \\
\text { composite }\end{array}$ & $\begin{array}{c}\text { Bone tissue } \\
\text { engineering- Human } \\
\text { mesenchymal stem } \\
\text { cells }\end{array}$ & $\begin{array}{l}30 \% \text { to } 40 \% \text { gelatin in nanofibers } \\
\text { provided optimum hydrophilicity, } \\
\text { degradability and promoted } \\
\text { cell growth }\end{array}$ & Binulal et al. [66] & 2014 \\
\hline PCL/laminin & $\begin{array}{l}\text { Human embryonic } \\
\text { stem cell culture }\end{array}$ & $\begin{array}{c}\text { Fiber diameter }=31-780 \mathrm{~nm}, \\
\text { promoted peripheral } \\
\text { nerve regeneration }\end{array}$ & Neal et al. [73] & 2014 \\
\hline $\begin{array}{l}\text { PCL/gelatin } \\
\text { composite }\end{array}$ & $\begin{array}{c}\text { Muscle tissue } \\
\text { engineering- myoblasts }\end{array}$ & $\begin{array}{l}\text { Genipin as a crosslinking agent, } \\
\text { average fiber diameter }=250-350 \\
\text { nm, promising cell proliferation }\end{array}$ & Kim et al. [67] & 2010 \\
\hline PCL & $\begin{array}{l}\text { Human mesenchymal } \\
\text { cell growth }\end{array}$ & $\begin{array}{c}\text { Fiber average diameter }=277 \mathrm{~nm}, \\
\text { Nanofibers promote cell } \\
\text { attachment, spreading and } \\
\text { differentiation compared } \\
\text { to microfibers }\end{array}$ & Binulal et al. [74] & 2010 \\
\hline PCL & $\begin{array}{l}\text { Human umbilical vein } \\
\text { endothelial cells }\end{array}$ & $\begin{array}{l}700 \mathrm{~nm} \text { fibers coated with } \\
\text { poly(dopamine)(PDA), enhanced } \\
\text { cell adhesion with an expression } \\
\text { of cell markers }\end{array}$ & Ku et al. [75] & 2010 \\
\hline
\end{tabular}

PCL, Polycaprolactone; PLA, Poly lactic acid; PLGA, Poly lactic-co-glycolic acid; PVA, polyvinyl alcohol; PMMA, Poly(methyl methacrylate). 
Electrospinning of BM protein laminin-I was first performed by Neal et al. to produce nanofibers about 90-300 nm diameter [73]. They observed that, unlike collagen, laminin fibers were stable in culture without any fixation by chemical crosslinking, and human adipose stem cells showed superior adhesion quality compared to laminin films [76]. A subsequent study by this group using PCL/laminin blend also showed similar results [73]. BM mimics are considered as the major requirement to produce a successful tissue engineered skin, vascular graft and invitro alveolar models [77-80]. Frazer et al. electrospun trilayer BM mimic, made of a single layer of nanofibrous polyhydroxyvalerate, interwoven at both sides by microfibrous poly L lactic acid. This BM mimic not only increased the attachment and proliferation of keratinocytes and fibroblasts but also encouraged the self-sorting of these cells into epithelial and dermal layers [77]. Similarly, a BM substitute produced by coelectrospinning a tripeptide derived from BM type IV collagen, along with PCL had an innate ability to control the ratio of endothelial to smooth muscle cells, a characteristic feature required to produce a successful vascular graft [78]. In vitro alveolar models to study the lung physiology and lung inflammatory reactions have also used electrospun BM mimics $[79,80]$. It was observed that epithelial and endothelial cells grown on these BM mimic better replicate the alveolar environment and its functions [80]. Recent studies were successful in producing poloxamer 188 based nanofibers by co-electrospinning it with other polymers (polyacrylonitrile, poly(vinyl alcohol)/poly(vinyl pyrrolidone)-iodine) [81,82]. Poloxamer 188 is a non-ionic surfactant, which can increase the viability and proliferation of cells that were damaged due to multiple sub-culturing, pipetting, cryostorage and thawing [83].

To impart complex spatial arrangements and dimensions into the scaffold, different types of electrospinning techniques have evolved, which could relatively fabricate the structural complexity of natural ECM compared to conventional electrospinning [84]. Dual extrusion electrospinning is one such example, which permits two different polymeric solutions to be electrospun simultaneously using different extrusion conditions [85]. This was performed by Kim et al. whose hybrid scaffold made of silk fibroin nanofibers and PCL microfibers showed an increase in osteoblast cell differentiation [86]. Coaxial electrospinning is another technique which uses two different polymer solutions. However, they are fed into the spinneret as inner and outer fluid to produce fibers with a different core and shell composition [87]. This feature has increased its significance not only in the field of tissue engineering but also in drug delivery, as these fibers have the capacity to encapsulate drugs, growth factors and antibiotics [87]. Temperature-assisted electrospinning methods such as cryogenic electrospinning and melt electrospinning are also used and can program the desired porosity into the scaffold [88,89]. Cryogenic electrospinning method uses ice crystals, spun along with the fibrous scaffold, which when removed by freeze drying leave behind voids through which cells can infiltrate [88]. The porosity can be controlled based on the size and amount of the ice crystals used [88]. Temperature-assisted electrospinning, on the other hand, uses a melt blowing technology, where the polymer is melted with high temperature and is extruded out using controlled air flow [89]. This method can produce aligned fibers with desired porosity and hence was used to replicate the ECM environment of tendons $[89,90]$. However, none of the above methods provide complete control over the fiber alignment and its 3D deposition. This has led researchers to use 3D printing technology in electrospinning [91,92]. Near field-electrospinning is a relatively new method that prevents the bending and splitting instabilities of the electrospun fibers by reducing the distance between the spinneret and collector to a bare minimum $(<3 \mathrm{~mm})$. Lu et al. included a 3D printing technology into this method by controlling the fibers deposition in a pre-programmed X-Y path [91]. Fattahi et al. went a step further and used X-Y-Z moving stage (which replicates the technology used in hobbyist grade 3D printers) to produce a highly organized scaffold with 3D architecture [92]. More recently, a technique referred to as 3D jet writing a modified electrospinning process, which yields $3 \mathrm{D}$ structures and scaffolds that have been shown to support the 3D expansion and differentiation of human mesenchymal stem cells in vitro (Figure 1) [93]. 

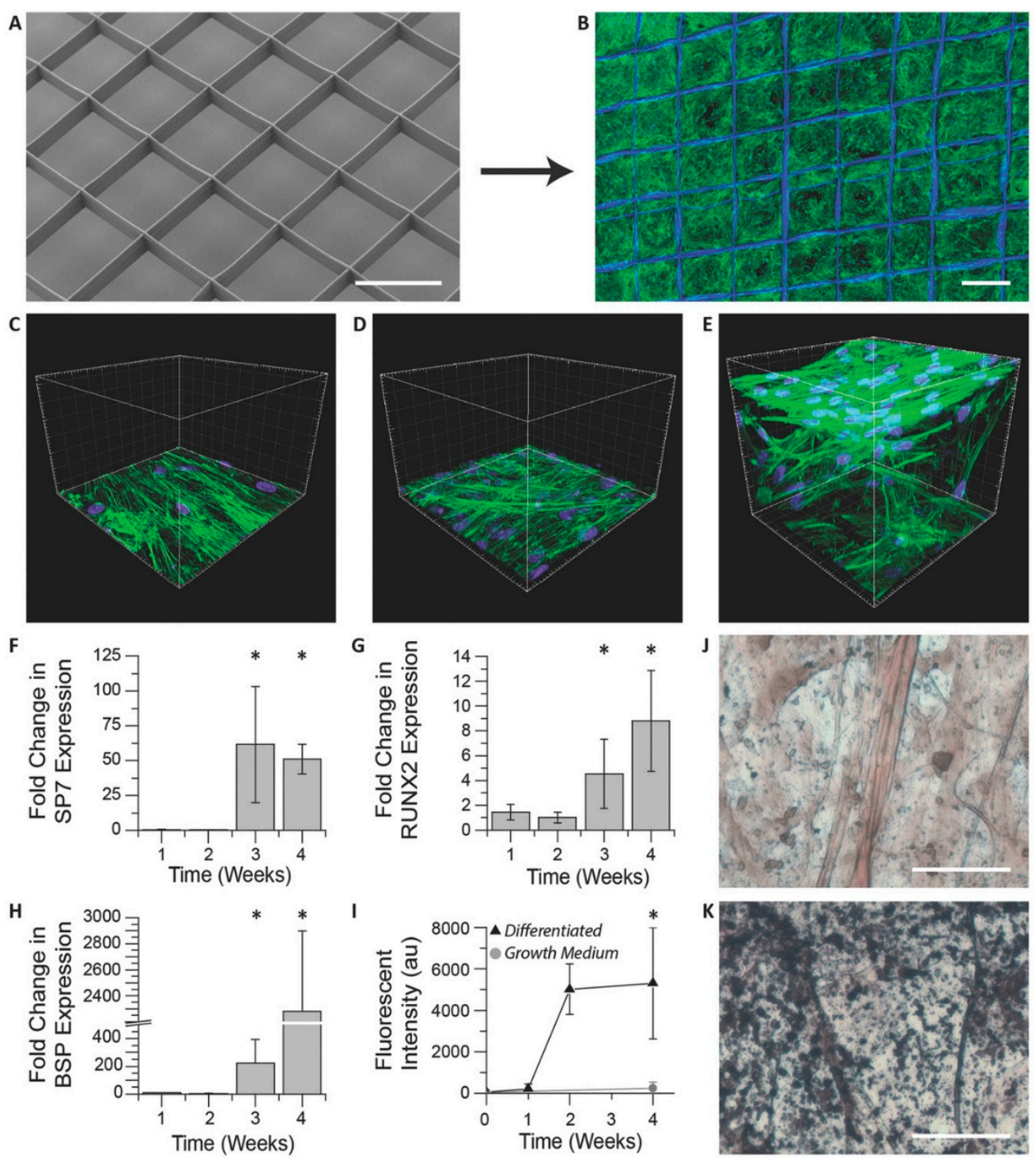

Figure 1. In vitro hMSC culture on $3 \mathrm{D}$ jet writing scaffolds produces $3 \mathrm{D}$ microtissues. (A,B) $3 \mathrm{D}$ microfiber scaffolds were incubated with fibronectin and seeded with hMSCs to yield confluent cell structures. (C-E) hMSCs cultured on scaffolds (E) reveal significantly different morphologies and spatial distribution (3D) than cultures on glass (C), or nonwoven PLGA fiber mats (D) (both 2D). (F-H) hMSCs on scaffolds were incubated in osteogenic differentiation media and monitored using qPRC. The markers SP7 (F), RUNX2 (G), and BSP (H) were used as indicators of osteogenic differentiation. Values reported are fold increases over hMSCs cultured in growth medium. Large increases in these markers after three weeks are consistent with the onset of osteogenesis. Error bars represent \pm Std. Dev from three independent experiments. (I) Fluorescent staining of scaffolds for hydroxyapatite reveal substantial increases in matrix mineralization after two weeks of differentiation. $(\mathbf{J}, \mathbf{K})$ Von Kossa staining of hMSCs incubated in growth medium (J) show little matrix mineralization compared to that seen in samples differentiated in osteogenic induction medium indicated by the black aggregates (K). Scale bars represent: $500 \mu \mathrm{m}(\mathbf{A}, \mathbf{B}) ; 50 \mu \mathrm{m}(\mathbf{J}, \mathbf{K})$; and the spacings between large grids are $20 \mu \mathrm{m}(\mathbf{C}-\mathbf{E})$. Reproduced with permission from [93], Copyright WILEY-VCH Verlag GmbH \& Co. KGaA, 2018.

All the above examples clearly indicate the rapid progression of research in the field of electrospinning and scaffold technology to produce a structurally programmable and low-cost ECM or $\mathrm{BM}$ mimics for tissue engineering applications. 


\subsection{Applications of Electrospun Nano Structures for Drug Delivery Purposes}

Biomimetic electrospun nanofibers have the potential to be used as efficient drug carrier systems. For instance, biomimetic electrospun polyamidoamine dendrimer/gelatin nanofibrous scaffold carrying antibiotic doxycycline was produced by Freshwater et al., which exhibited efficient wound healing property by controlled drug release [94]. Similarly, sandwiched electrospun ECM biomimic made from PLGA/collagen surface and PLGA/antibiotic drug core enabled wound healing by prolonged drug release for more than three weeks [95]. The bone ECM was mimicked in another study where bone morphogenetic protein 2 (BMP-2) was embedded into electrospun silk fibroin/hyaluronic acid nanofibers to use in bone repair applications [96]. Silk fibroin/hyaluronic acid biomimetic nanofibers were demonstrated to act as excellent carriers for hydrophilic drugs [97]. This clearly indicates the growing significance of biomimetic nanofibers in drug delivery applications.

\section{Conclusions}

A major challenge in creating a BM analog has been mimicking its complex chemical and physical characteristics. Although electrospinning is a well-established technique, its use to create a BM mimetic is in its early stages. Further research is required to optimize the electrospinning method to produce homogeneous nanofibers with physicochemical, structural (including microscale architecture), and biological properties that closely resemble the BM. While scaffolds made from natural polymers are known for their innate ability to promote cell growth, they are currently less preferable due to lower stability and faster degradation rates. However, with continuous advancement in the electrospinning technique, production of synthetic alternatives that more closely resemble the native BM is becoming a viable perspective. The ultimate goal is to produce synthetic BM mimetics at a low cost with versatile applications in the field of regenerative medicine and for the creation of improved in vitro models.

Author Contributions: All authors contributed to designing the structure and content of the article; S.K.P. drafted the manuscript; D.V. and B.T.R,-A, critically appraised and provided further discussion for the article. All authors have approved the submitted final version of the article.

Funding: This research received no external funding.

Conflicts of Interest: The authors declare no conflict of interest.

\section{References}

1. Cruz-Acuña, R.; García, A. Synthetic hydrogels mimicking basement membrane matrices to promote cell-matrix interactions. Matrix Biol. 2017, 57-58, 324-333. [CrossRef] [PubMed]

2. Garland, S.; McKee, C.; Chang, Y.; Raghunathan, V.; Russell, P.; Murphy, C. A Cell Culture Substrate with Biologically Relevant Size-Scale Topography and Compliance of the Basement Membrane. Langmuir 2014, 30, 2101-2108. [CrossRef] [PubMed]

3. Vllasaliu, D.; Falcone, F.; Stolnik, S.; Garnett, M. Basement membrane influences intestinal epithelial cell growth and presents a barrier to the movement of macromolecules. Exp. Cell. Res. 2014, 323, 218-231. [CrossRef] [PubMed]

4. Ma, T.; Boivin, M.; Ye, D.; Pedram, A.; Said, H. Mechanism of TNF- $\alpha$ modulation of Caco-2 intestinal epithelial tight junction barrier: Role of myosin light-chain kinase protein expression. Am. J. Physiol.-Gastrointest. Liver Physiol. 2005, 288, G422-G430. [CrossRef] [PubMed]

5. Rescigno, M.; Urbano, M.; Valzasina, B.; Francolini, M.; Rotta, G.; Bonasio, R.; Granucci, F.; Kraehenbuhl, J.; Ricciardi-Castagnoli, P. Dendritic cells express tight junction proteins and penetrate gut epithelial monolayers to sample bacteria. Nat. Immunol. 2001, 2, 361-367. [CrossRef] [PubMed]

6. Fowler, R.; Vllasaliu, D.; Trillo, F.; Garnett, M.; Alexander, C.; Horsley, H.; Smith, B.; Whitcombe, I.; Eaton, M.; Stolnik, S. Nanoparticle Transport in Epithelial Cells: Pathway Switching Through Bioconjugation. Small 2013, 9, 3282-3294. [CrossRef] [PubMed]

7. Dix, C.; Hassan, I.; Obray, H.; Shah, R.; Wilson, G. The Transport of Vitamin B12 Through Polarized Monolayers of Caco-2 Cells. Gastroenterology 1990, 98, 1272-1279. [CrossRef] 
8. Tocce, E.; Liliensiek, S.; Wilson, M.; Yanez-Soto, B.; Nealey, P.; Murphy, C. Engineering the Biophysical Properties of Basement Membranes into Biomaterials: Fabrication and Effects on Cell Behavior. Compre. Biomater. 2011, 527-546.

9. Bajaj, P.; Schweller, R.; Khademhosseini, A.; West, J.; Bashir, R. 3D Biofabrication Strategies for Tissue Engineering and Regenerative Medicine. Annu. Rev. Biomed. Eng. 2014, 16, 247-276. [CrossRef] [PubMed]

10. Xue, J.; Xie, J.; Liu, W.; Xia, Y. Electrospun Nanofibers: New Concepts, Materials, and Applications. Acc. Chem. Res. 2017, 50, 1976-1987. [CrossRef] [PubMed]

11. Merker, H. Morphology of the basement membrane. Microsc. Res. Tech. 1994, 28, 95-124. [CrossRef] [PubMed]

12. Morrissey, M.; Sherwood, D. An active role for basement membrane assembly and modification in tissue sculpting. J. Cell Sci. 2015, 128, 1661-1668. [CrossRef] [PubMed]

13. Fidler, A.; Vanacore, R.; Chetyrkin, S.; Pedchenko, V.; Bhave, G.; Yin, V.; Stothers, C.; Rose, K.; McDonald, W.; Clark, T.; et al. A unique covalent bond in basement membrane is a primordial innovation for tissue evolution. Proc. Natl. Acad. Sci. 2013, 111, 331-336. [CrossRef] [PubMed]

14. El Ghalbzouri, A.; Ponec, M. Diffusible factors released by fibroblasts support epidermal morphogenesis and deposition of basement membrane components. Wound Repair Regen. 2004, 12, 359-367. [CrossRef] [PubMed]

15. Glentis, A.; Gurchenkov, V.; Vignjevic, D. Assembly, heterogeneity, and breaching of the basement membranes. Cell Adhes. Migrat. 2014, 8, 236-245. [CrossRef]

16. Kruegel, J.; Miosge, N. Basement membrane components are key players in specialized extracellular matrices. Cell. Mol. Life Sci. 2010, 67, 2879-2895. [CrossRef] [PubMed]

17. Kelley, L.; Lohmer, L.; Hagedorn, E.; Sherwood, D. Traversing the basement membrane in vivo: A diversity of strategies. J. Cell Biol. 2014, 204, 291-302. [CrossRef] [PubMed]

18. Yurchenco, P. Basement Membranes: Cell Scaffoldings and Signaling Platforms. Cold Spring Harb. Perspect. Biol. 2010, 3, a004911. [CrossRef] [PubMed]

19. Wiradjaja, F.; DiTommaso, T.; Smyth, I. Basement membranes in development and disease. Birth Defects Res. Part C: Embryo Today: Rev. 2010, 90, 8-31. [CrossRef] [PubMed]

20. Iozzo, R.; Zoeller, J.; Nyström, A. Basement membrane proteoglycans: Modulators Par Excellence of cancer growth and angiogenesis. Mol. and Cells 2009, 27, 503-513. [CrossRef] [PubMed]

21. Denning, D.; Roos, W. Elucidating the molecular mechanisms underlying cellular response to biophysical cues using synthetic biology approaches. Cell Adhes. Migrat. 2016, 10, 540-553. [CrossRef] [PubMed]

22. Flemming, R.; Murphy, C.; Abrams, G.; Goodman, S.; Nealey, P. Effects of synthetic micro- and nano-structured surfaces on cell behavior. Biomaterials 1999, 20, 573-588. [CrossRef]

23. Discher, D. Tissue Cells Feel and Respond to the Stiffness of Their Substrate. Science 2005, 310, 1139-1143. [CrossRef] [PubMed]

24. Schittny, J. High resolution immunoelectron microscopic localization of functional domains of laminin, nidogen, and heparan sulfate proteoglycan in epithelial basement membrane of mouse cornea reveals different topological orientations. J. Cell Biol. 1988, 107, 1599-1610. [CrossRef] [PubMed]

25. Yurchenco, P.; Patton, B. Developmental and Pathogenic Mechanisms of Basement Membrane Assembly. Curr. Pharm. Des. 2009, 15, 1277-1294. [CrossRef] [PubMed]

26. Halfter, W.; Oertle, P.; Monnier, C.; Camenzind, L.; Reyes-Lua, M.; Hu, H.; Candiello, J.; Labilloy, A.; Balasubramani, M.; Henrich, P.; et al. New concepts in basement membrane biology. FEBS J. 2015, 282, 4466-4479. [CrossRef] [PubMed]

27. Candiello, J.; Cole, G.; Halfter, W. Age-dependent changes in the structure, composition and biophysical properties of a human basement membrane. Matrix Biol. 2010, 29, 402-410. [CrossRef] [PubMed]

28. Candiello, J.; Balasubramani, M.; Schreiber, E.; Cole, G.; Mayer, U.; Halfter, W.; Lin, H. Biomechanical properties of native basement membranes. FEBS J. 2007, 274, 2897-2908. [CrossRef] [PubMed]

29. Henrich, P.; Monnier, C.; Halfter, W.; Haritoglou, C.; Strauss, R.; Lim, R.; Loparic, M. Nanoscale Topographic and Biomechanical Studies of the Human Internal Limiting Membrane. Invest. Opthalmol. Vis. Sci. 2012, 53, 2561. [CrossRef] [PubMed]

30. Halfter, W.; Monnier, C.; Müller, D.; Oertle, P.; Uechi, G.; Balasubramani, M.; Safi, F.; Lim, R.; Loparic, M.; Henrich, P. The Bi-Functional Organization of Human Basement Membranes. PLoS ONE 2013, 8, e67660. [CrossRef] [PubMed] 
31. Behrens, D.; Villone, D.; Koch, M.; Brunner, G.; Sorokin, L.; Robenek, H.; Bruckner-Tuderman, L.; Bruckner, P.; Hansen, U. The Epidermal Basement Membrane Is a Composite of Separate Laminin- or Collagen IV-containing Networks Connected by Aggregated Perlecan, but Not by Nidogens. J. Biol. Chem. 2012, 287, 18700-18709. [CrossRef] [PubMed]

32. Vázquez, F.; Palacios, S.; Alemañ, N.; Guerrero, F. Changes of the basement membrane and type IV collagen in human skin during aging. Maturitas 1996, 25, 209-215. [CrossRef]

33. Alvarado, J.; Murphy, C.; Juster, R. Age-related changes in the basement membrane of the human corneal epithelium. Invest. Ophthalmol. Visual Sci. 1983, 24, 1015-1028.

34. Richardson, LL.; Kleinman, HK.; Dym, M. The effects of aging on basement membrane in the testis. J. Androl. 1995, 16, 118-126. [PubMed]

35. Neumann, K.; Kellner, C.; Kuhn, K.; Stolte, H.; Schurek, H. Age-dependent thickening of glomerular basement membrane has no major effect on glomerular hydraulic conductivity. Nephrol. Dial. Transpl. 2004, 19, 805-811. [CrossRef] [PubMed]

36. Van Agtmael, T.; Bruckner-Tuderman, L. Basement membranes and human disease. Cell Tissue Res. 2009, 339, 167-188. [CrossRef] [PubMed]

37. Gubler, M. Inherited diseases of the glomerular basement membrane. Nat. Clin. Pract. Nephrol. 2008, 4, 24-37. [CrossRef] [PubMed]

38. Kayaselcuk, F.; Serin, E.; Gumurdulu, Y.; Ozer, B.; Tuncer, I.; Boyacioglu, S. Subepithelial basement membrane thickness in patients with normal colonic mucosal appearance in colonoscopy: Results from southern Turkey. World J. Gastroenterol. 2004, 10, 1056. [CrossRef]

39. Eltboli, O.; Mistry, V.; Barker, B.; Brightling, C. Relationship between blood and bronchial submucosal eosinophilia and reticular basement membrane thickening in chronic obstructive pulmonary disease. Respirology 2015, 20, 667-670. [CrossRef] [PubMed]

40. McAteer, JA.; Dougherty, GS.; Gardner, JK.; Evan, AP. Polarized epithelial cysts in vitro: A review of cell and explant culture systems that exhibit epithelial cyst formation. Scanning Microsc. 1988, 2, 1739-1763. [PubMed]

41. Haigo, S.; Bilder, D. Global Tissue Revolutions in a Morphogenetic Movement Controlling Elongation. Science 2011, 331, 1071-1074. [CrossRef] [PubMed]

42. Harunaga, J.; Doyle, A.; Yamada, K. Local and global dynamics of the basement membrane during branching morphogenesis require protease activity and actomyosin contractility. Dev. Biol. 2014, 394, 197-205. [CrossRef] [PubMed]

43. Obermeier, B.; Daneman, R.; Ransohoff, R. Development, maintenance and disruption of the blood-brain barrier. Nat. Med. 2013, 19, 1584-1596. [CrossRef] [PubMed]

44. Vllasaliu, D.; Thanou, M.; Stolnik, S.; Fowler, R. Recent advances in oral delivery of biologics: Nanomedicine and physical modes of delivery. Expert Opin. Drug Discovery 2018, 15, 759-770. [CrossRef] [PubMed]

45. Mantaj, J.; Abu-Shams, T.; Enlo-Scott, Z.; Swedrowska, M.; Vllasaliu, D. Role of the Basement Membrane as an Intestinal Barrier to Absorption of Macromolecules and Nanoparticles. Mol. Pharm. 2018, 15, 5802-5808. [CrossRef] [PubMed]

46. Alfano, M.; Chasens, A.; Masi, C. Autoradiographic study of the penetration of radiolabelled dextrans and inulin through non-keratinized oral mucosain vitro. J. Periodontal Res. 1977, 12, 368-377. [CrossRef] [PubMed]

47. Bhardwaj, N.; Kundu, S. Electrospinning: A fascinating fiber fabrication technique. Biotechnol. Adv. 2010, 28, 325-347. [CrossRef] [PubMed]

48. Doshi, J.; Reneker, D. Electrospinning process and applications of electrospun fibers. J. Electrostat. 1995, 35, 151-160. [CrossRef]

49. Ahmed, F.; Lalia, B.; Hashaikeh, R. A review on electrospinning for membrane fabrication: Challenges and applications. Desalin. 2015, 356, 15-30. [CrossRef]

50. Lu, W.; Sun, J.; Jiang, X. Recent advances in electrospinning technology and biomedical applications of electrospun fibers. J. Mater. Chem. B 2014, 2, 2369. [CrossRef]

51. Thavasi, V.; Singh, G.; Ramakrishna, S. Electrospun nanofibers in energy and environmental applications. Energy Environ. Sci. 2008, 1, 205. [CrossRef]

52. Eatemadi, A.; Daraee, H.; Zarghami, N.; Melat Yar, H.; Akbarzadeh, A. Nanofiber: Synthesis and biomedical applications. Artif. Cells Nanomed. Biotechnol. 2014, 44, 111-121. [CrossRef] [PubMed] 
53. Mirjalili, M.; Zohoori, S. Review for application of electrospinning and electrospun nanofibers technology in textile industry. J. Nanostruct. Chem. 2016, 6, 207-213. [CrossRef]

54. Pham, Q.; Sharma, U.; Mikos, A. Electrospinning of Polymeric Nanofibers for Tissue Engineering Applications: A Review. Tissue Eng. 2006, 12, 1197-1211. [CrossRef] [PubMed]

55. Li, W.; Laurencin, C.; Caterson, E.; Tuan, R.; Ko, F. Electrospun nanofibrous structure: A novel scaffold for tissue engineering. J. Biomed. Mater. Res. 2002, 60, 613-621. [CrossRef] [PubMed]

56. Mo, X.; Xu, C.; Kotaki, M.; Ramakrishna, S. Electrospun P(LLA-CL) nanofiber: A biomimetic extracellular matrix for smooth muscle cell and endothelial cell proliferation. Biomaterials 2004, 25, 1883-1890. [CrossRef] [PubMed]

57. Tuan, R.; Boland, G.; Tuli, R. Adult mesenchymal stem cells and cell-based tissue engineering. Arthritis Res. Ther. 2003, 5, 32. [CrossRef] [PubMed]

58. Li, W.; Tuli, R.; Huang, X.; Laquerriere, P.; Tuan, R. Multilineage differentiation of human mesenchymal stem cells in a three-dimensional nanofibrous scaffold. Biomaterials 2005, 26, 5158-5166. [CrossRef] [PubMed]

59. Manea, L.; Hristian, L.; Leon, A.; Popa, A. Recent advances of basic materials to obtain electrospun polymeric nanofibers for medical applications. IOP Conf. Ser. Mater. Sci. Eng. 2016, 145, 032006. [CrossRef]

60. Sell, S.; Wolfe, P.; Garg, K.; McCool, J.; Rodriguez, I.; Bowlin, G. The Use of Natural Polymers in Tissue Engineering: A Focus on Electrospun Extracellular Matrix Analogues. Polymers 2010, 2, 522-553. [CrossRef]

61. Matthews, J.; Wnek, G.; Simpson, D.; Bowlin, G. Electrospinning of Collagen Nanofibers. Biomacromolecules 2002, 3, 232-238. [CrossRef] [PubMed]

62. Barnes, C.; Sell, S.; Boland, E.; Simpson, D.; Bowlin, G. Nanofiber technology: Designing the next generation of tissue engineering scaffolds. Adv. Drug Delivery Rev. 2007, 59, 1413-1433. [CrossRef] [PubMed]

63. Zahari, N.; Idrus, R.; Chowdhury, S. Laminin-Coated Poly(Methyl Methacrylate) (PMMA) Nanofiber Scaffold Facilitates the Enrichment of Skeletal Muscle Myoblast Population. Int. J. Mol. Sci. 2017, 18, 2242. [CrossRef] [PubMed]

64. Kidoaki, S.; Kwon, I.; Matsuda, T. Mesoscopic spatial designs of nano- and microfiber meshes for tissue-engineering matrix and scaffold based on newly devised multilayering and mixing electrospinning techniques. Biomaterials 2005, 26, 37-46. [CrossRef] [PubMed]

65. Fesharaki, M.; Razavi, S.; Ghasemi-Mobarakeh, L.; Behjati, M.; Yarahmadian, R.; Kazemi, M.; Hejazi, H. Differentiation of Human Scalp Adipose-Derived Mesenchymal Stem Cells into Mature Neural Cells on Electrospun Nanofibrous Scaffolds for Nerve Tissue Engineering Applications. Cell J. (Yakhteh). 2018, 20.

66. Binulal, N.; Natarajan, A.; Menon, D.; Bhaskaran, V.; Mony, U.; Nair, S. PCL-gelatin composite nanofibers electrospun using diluted acetic acid-ethyl acetate solvent system for stem cell-based bone tissue engineering. J. Biomater. Sci. Polym. Ed. 2013, 25, 325-340. [CrossRef] [PubMed]

67. Kim, M.; Jun, I.; Shin, Y.; Jang, W.; Kim, S.; Shin, H. The Development of Genipin-Crosslinked Poly(caprolactone) (PCL)/Gelatin Nanofibers for Tissue Engineering Applications. Macromol. Biosci. 2010, 10, 91-100. [CrossRef] [PubMed]

68. Li, X.; Yan, S.; Dai, J.; Lu, Y.; Wang, Y.; Sun, M.; Gong, J.; Yao, Y. Human lung epithelial cells A549 epithelial-mesenchymal transition induced by PVA/Collagen nanofiber. Colloids Surf. B 2018, 162, 390-397. [CrossRef] [PubMed]

69. Haddad, T.; Noel, S.; Liberelle, B.; El Ayoubi, R.; Ajji, A.; De Crescenzo, G. Fabrication and surface modification of poly lactic acid (PLA) scaffolds with epidermal growth factor for neural tissue engineering. Biomatter 2016, 6, e1231276. [CrossRef] [PubMed]

70. Lafond, E.; Lawson, A.; Niemeier, R.; Cady, C.; Nair, K. Biocompatibility of human Whartons Jelly Mesenchymal Stem Cells on poly-caprolactone and collagen based nanofiber mats. In Proceedings of the 2015 41st Annual Northeast Biomedical Engineering Conference (NEBEC), Troy, NY, USA, 17-19 April 2015; pp. 1-2.

71. Shalumon, K.; Deepthi, S.; Anupama, M.; Nair, S.; Jayakumar, R.; Chennazhi, K. Fabrication of poly (l-lactic acid)/gelatin composite tubular scaffolds for vascular tissue engineering. Int. J. Biol. Macromol. 2015, 72, 1048-1055. [CrossRef] [PubMed]

72. Mehrasa, M.; Asadollahi, M.; Ghaedi, K.; Salehi, H.; Arpanaei, A. Electrospun aligned PLGA and PLGA/gelatin nanofibers embedded with silica nanoparticles for tissue engineering. Int. J. Biol. Macromol. 2015, 79, 687-695. [CrossRef] [PubMed] 
73. Neal, R.; Lenz, S.; Wang, T.; Abebayehu, D.; Brooks, B.; Ogle, R.; Botchwey, E. Laminin- and basement membranepolycaprolactone blend nanofibers as a scaffold for regenerative medicine. Nanomater. Environ. 2014, 2. [CrossRef] [PubMed]

74. Binulal, N.; Deepthy, M.; Selvamurugan, N.; Shalumon, K.; Suja, S.; Mony, U.; Jayakumar, R.; Nair, S. Role of Nanofibrous Poly(Caprolactone) Scaffolds in Human Mesenchymal Stem Cell Attachment and Spreading for In Vitro Bone Tissue Engineering—Response to Osteogenic Regulators. Tissue Eng. Part A 2010, 16, 393-404. [CrossRef] [PubMed]

75. Ku, S.; Park, C. Human endothelial cell growth on mussel-inspired nanofiber scaffold for vascular tissue engineering. Biomaterials 2010, 31, 9431-9437. [CrossRef] [PubMed]

76. Neal, R.; McClugage, S.; Link, M.; Sefcik, L.; Ogle, R.; Botchwey, E. Laminin Nanofiber Meshes That Mimic Morphological Properties and Bioactivity of Basement Membranes. Tissue Eng. Part C 2009, 15, 11-21. [CrossRef] [PubMed]

77. Bye, F.; Bullock, A.; Singh, R.; Sefat, F.; Roman, S.; MacNeil, S. Development of a Basement Membrane Substitute Incorporated Into an Electrospun Scaffold for 3D Skin Tissue Engineering. J. Biomater. Tissue Eng. 2014, 4, 686-692. [CrossRef]

78. Kanie, K.; Narita, Y.; Zhao, Y.; Kuwabara, F.; Satake, M.; Honda, S.; Kaneko, H.; Yoshioka, T.; Okochi, M.; Honda, H.; et al. Collagen type IV-specific tripeptides for selective adhesion of endothelial and smooth muscle cells. Biotechnol. Bioeng. 2012, 109, 1808-1816. [CrossRef] [PubMed]

79. Dohle, E.; Singh, S.; Nishigushi, A.; Fischer, T.; Wessling, M.; Möller, M.; Sader, R.; Kasper, J.; Ghanaati, S.; Kirkpatrick, C. Human Co- and Triple-Culture Model of the Alveolar-Capillary Barrier on a Basement Membrane Mimic. Tissue Eng. Part C 2018, 24, 495-503. [CrossRef] [PubMed]

80. Nishiguchi, A.; Singh, S.; Wessling, M.; Kirkpatrick, C.; Möller, M. Basement Membrane Mimics of Biofunctionalized Nanofibers for a Bipolar-Cultured Human Primary Alveolar-Capillary Barrier Model. Biomacromolecules 2017, 18, 719-727. [CrossRef] [PubMed]

81. Böttjer, R.; Grothe, T.; Wehlage, D.; Ehrmann, A. Electrospraying poloxamer/(bio-)polymer blends using a needleless electrospinning machine. J. Textiles Fibrous Mater. 2018, 1, 2515221117743079. [CrossRef]

82. Aytimur, A.; Koçyiğit, S.; Uslu, İ. Synthesis and Characterization of Poly(vinyl alcohol)/Poly(vinyl pyrrolidone)-Iodine Nanofibers with Poloxamer 188 and Chitosan. Polym. Plast. Technol. Eng. 2013, 52, 661-666. [CrossRef]

83. Kerleta, V.; Andrlik, I.; Braunmuller, S.; Franke, T.; Wirth, M.; Gabor, F. Poloxamer 188 supplemented culture medium increases the vitality of Caco-2 cells after subcultivation and freeze/thaw cycles. Altex 2010, 27, 191-197. [CrossRef]

84. Jun, I.; Han, H.; Edwards, J.; Jeon, H. Electrospun Fibrous Scaffolds for Tissue Engineering: Viewpoints on Architecture and Fabrication. Int. J. Mol. Sci. 2018, 19, 745. [CrossRef] [PubMed]

85. Levorson, E.; Raman Sreerekha, P.; Chennazhi, K.; Kasper, F.; Nair, S.; Mikos, A. Fabrication and characterization of multiscale electrospun scaffolds for cartilage regeneration. Biomed. Mater. 2013, 8, 014103. [CrossRef] [PubMed]

86. Kim, B.S.; Park, K.E.; Kim, M.H.; You, H.K.; Lee, J.; Park, W.H. Effect of nanofiber content on bone regeneration of silk fibroin/poly(epsilon-caprolactone) nano/microfibrous composite scaffolds. Int. J. Nanomed. 2015, 10, 485-502.

87. Lu, Y.; Huang, J.; Yu, G.; Cardenas, R.; Wei, S.; Wujcik, E.; Guo, Z. Coaxial electrospun fibers: Applications in drug delivery and tissue engineering. Wiley Interdiscip. Rev. Nanomed. Nanobiotechnol. 2016, 8, 654-677. [CrossRef] [PubMed]

88. Bulysheva, A.A.; Bowlin, G.L.; Klingelhutz, A.J.; Yeudall, W.A. Low-temperature electrospun silk scaffold for in vitro mucosal modeling. J. Biomed. Mater. Res. A 2012, 100A, 757-767. [CrossRef] [PubMed]

89. Tourlomousis, F.; Ding, H.; Kalyon, D.M.; Chang, R.C. Melt Electrospinning Writing Process Guided by a "Printability Number". J. Manuf. Sci. Eng. 2017, 139, 081004. [CrossRef]

90. Jenkins, T.L.; Meehan, S.; Pourdeyhimi, B.; Little, D. Meltblown Polymer Fabrics as Candidate Scaffolds for Rotator Cuff Tendon Tissue Engineering. Tissue Eng. Part A 2017, 23, 958-967. [CrossRef] [PubMed]

91. Luo, G.X.; Teh, K.S.; Zang, X.N.; Wu, D.Z.; Wen, Z.Y.; Lin, L.W. High Aspect-Ratio 3d Microstructures Via near-Field Electrospinning for Energy Storage Applications. In Proceedings of the 2016 IEEE 29th International Conference on Micro Electro Mechanical Systems (MEMS), Shanghai, China, 24-28 January 2016; pp. 29-32. 
92. Fattahi, P.; Dover, J.T.; Brown, J.L. 3D Near-Field Electrospinning of Biomaterial Microfibers with Potential for Blended Microfiber-Cell-Loaded Gel Composite Structures. Adv. Healthc. Mater. 2017, 6, 1700456. [CrossRef] [PubMed]

93. Jordahl, J.; Solorio, L.; Sun, H.; Ramcharan, S.; Teeple, C.; Haley, H.; Lee, K.; Eyster, T.; Luker, G.; Krebsbach, P.; et al. 3D Jet Writing: Functional Microtissues Based on Tessellated Scaffold Architectures. Adv. Mater. 2018, 30, 1707196. [CrossRef] [PubMed]

94. Smith-Freshwater, A.; Bowlin, G.; Yang, H. A Novel Electrospun Dendrimer-Gelatin Hybrid Nanofiber Scaffold for Tissue Regeneration and Drug Delivery. MRS Proc. 2008, 1094, DD1009-DD1007. [CrossRef]

95. Chen, D.W.C.; Liao, J.Y.; Liu, S.J.; Chan, E.C. Novel biodegradable sandwich-structured nanofibrous drug-eluting membranes for repair of infected wounds: An in vitro and in vivo study. Int. J. Nanomed. 2012, 7, 763-771.

96. Ding, Z.; Fan, Z.; Huang, X.; Lu, Q.; Xu, W.; Kaplan, D. Silk-Hydroxyapatite Nanoscale Scaffolds with Programmable Growth Factor Delivery for Bone Repair. ACS Appl. Mater. Interfaces 2016, 8, 24463-24470. [CrossRef] [PubMed]

97. Zhang, K.; Fan, L.; Yan, Z.; Yu, Q.; Mo, X. Electrospun Biomimic Nanofibrous Scaffolds of Silk Fibroin/Hyaluronic Acid for Tissue Engineering. J. Biomater. Sci. Polym. Ed. 2012, ahead-of-print, 1-14. [CrossRef] [PubMed]

(C) 2019 by the authors. Licensee MDPI, Basel, Switzerland. This article is an open access article distributed under the terms and conditions of the Creative Commons Attribution (CC BY) license (http://creativecommons.org/licenses/by/4.0/). 